\title{
Ultrafiltration for the recovery of proteins from surimi washing water
}

\author{
Dayse Lícia de OLIVEIRA ${ }^{1 *}$ (D), Thiago Luís Magnani GRASSI ${ }^{1}$, Natália Mingues PAIVA ${ }^{1}$, \\ Bruna Nicoleti SANTANA ${ }^{1}$, Alex Akira NAKAMURA ${ }^{1}$, Rubén BERMEJO-POZA², Elisa Helena Giglio PONSANO ${ }^{1}$
}

\begin{abstract}
The aim of this study was to evaluate the efficiency of the ultrafiltration process (UF) in the cleansing treatment of the tilapia surimi washing water and in the recovery of components. After producing surimi, the water generated in the washing operations was subjected to UF in a $30 \mathrm{kDa}$ polyethersulfone membrane. Unfiltered washing waters and UF permeate and concentrate were analyzed for $\mathrm{pH}$, total solids (TS) and fixed solids (FS), total proteins, and lipids. The chemical oxygen demand (COD) was determined in the original water and in the permeate. The concentrate was dehydrated in a spray dryer and analyzed for amino acids and carotenoids. The permeate showed a significant decrease in TS, proteins and COD, indicating that UF was efficient in removing the organic load from the waters. The percentage of protein recovery by UF was $93.12 \%$ and the dehydrated concentrate had all the essential amino acids, being leucine (5.47\%), lysine (6.49\%), valine (3.59\%), and phenylalanine (3.68\%) those with the highest concentrations, and also $0.67 \mathrm{mg} / 100 \mathrm{~g}$ of carotenoids. The application of UF has proved to be viable both in the recovery of valuable compounds and in the decontamination of water, contributing to the sustainability of the fish productive sector.
\end{abstract}

Keywords: membrane filtration; chemical oxygen demand; essential amino acids.

Practical Application: The application of ultrafiltration (UF) in the surimi washing waters reduced the organic matter, allowing their disposal and reuse in the industrial process, in addition to recovering potentially polluting substances. The proteins recovered by UF from the surimi washing waters contain all essential amino acids, suggesting its use as a supplement, both in the form of fortified foods and supplements itself, very popular among athletes and people with high physical activity.

\section{Introduction}

According to Food and Agriculture Organization (2016), fishing and aquaculture are important sources of food, nutrition, income and livelihoods for thousands of people worldwide. In 2017, global per capita consumption of fish reached $20.5 \mathrm{~kg}$ (Food and Agriculture Organization, 2018), being 30-40\% fresh and $60-70 \%$ processed products (Park \& Morrissey, 2000).

Industrial fish processing and conservation techniques require water in large quantities, practically in all stages of production (Liu, 2007). However, for surimi production, the volume of water used is even greater, due to the washing operations of the fish muscle (Afonso \& Bórquez, 2002). For example, for cleaning, grinding and washing fish, about $5.7 \mathrm{~L}$ of water are used per $\mathrm{kg}$ of raw fish, which are divided into $35 \%$ for cleaning and grinding and 65\% for washing (Huang et al., 1997).

Washing processes carried out in the production of surimi eliminate soluble proteins, heme pigments and carotenoids, whose presence interferes in the formation of gels and can cause undesirable coloring in the final product (Galvão et al., 2012; Lee, 1984; Suzuki, 1987). The large volume of water rich in organic matter generated after the production of surimi represents an environmental problem, because when discarded in the sewage collection system without proper treatment, it causes the pollution of water masses (Huang \& Morrissey, 1998; Lin \& Park, 1996).
An alternative to reduce organic matter content in the surimi washing waters and treatment costs is the recovery of compounds with potential as pollutants, including proteins. The surimi washing waters contain $0.5-2.3 \%$ of proteins, composed mainly of sarcoplasmic, with small amounts of myofibrillar (myosin and actin) (Lin \& Park, 1996; Stine et al., 2012). The recovery of these proteins by membrane technology, especially by ultrafiltration (UF), allows the treatment of water and its reuse at the industry or its direct elimination in water masses, in addition to simultaneous recovery and concentration of proteins, without the use of heat or chemicals (Afonso \& Bórquez, 2002).

Due to the growing concern about the negative impact resulting from the release of effluents into the environment and the possibility of obtaining a by-product with application in the food industry, the objective of this study was to evaluate the efficiency of the UF process in the cleansing treatment of surimi washing waters and protein recovery.

\section{Materials and methods}

\subsection{Surimi processing}

Cuttings of tilapia fillets (Oreochromis niloticus) resulting from filleting were ground and subjected to three successive 
washes with distilled water at $6{ }^{\circ} \mathrm{C}$ for $5 \mathrm{~min}$, with $5 \mathrm{~min}$ of repose between washes, using the proportion of 3:1 (water: meat) (Oliveira et al., 2017). After each wash, the water was drained using ballerina fabric ( $100 \%$ polyester), collected (approximately $72 \mathrm{~L}$ ), and reserved. The procedure was repeated 8 times in the same day, yielding $82 \%$. Then, the washing waters were analyzed and destined for UF.

\subsection{Ultrafiltration of surimi washing waters}

The UF was performed on a $30 \mathrm{kDa}$ polyethersulfone membrane, model FE10-FC-FUS0382, with an area of $5.0 \mathrm{~m}^{2}$, at room temperature $\left(29 \pm 3{ }^{\circ} \mathrm{C}\right.$ ) and 2 bar (Figure 1). Liquid flow and operating time were regulated in order to minimize the clogging of the membrane.

\subsection{Characterization of surimi washing waters (original), concentrate and permeate}

The determinations of $\mathrm{pH}$ ( $\mathrm{pH}$-meter), total solids (TS) (evaporation in a water bath and oven at $105^{\circ} \mathrm{C}$ ), fixed solids (FS) (incineration at $550{ }^{\circ} \mathrm{C}$ ) and lipids (OG) (filtration in celite and Soxhlet extraction) were performed according to the techniques described in American Public Health Association (2005). Proteins were determined using the bicinchoninic acid (BCA) method, using a commercial BCA Protein Assay kit. All analyses were performed on the water obtained from the surimi washes (original) and after the UF process (concentrate and permeate). The chemical oxygen demand (COD) was measured in the original waters and in the permeate, after chemical digestion at $150{ }^{\circ} \mathrm{C}$ for $120 \mathrm{~min}$ (Hach $\left.{ }^{\circledast} \mathrm{DRB}-200\right)$ and reading at $435 \mathrm{~nm}\left(\mathrm{Hach}^{\oplus} \mathrm{DR}-2800\right)$. All analyses were performed in triplicate.

\subsection{Proteins recovery}

The percentage of recovered proteins was assessed using the following Equation 1 (Yeong et al., 2002):

$R p(\%)=\frac{C a-C b}{C a} \times 100$

where Rp: Proteins recovery; Ca: Protein concentration in surimi washing waters (original); $\mathrm{Cb}$ : Protein concentration in permeate.

\subsection{Electrophoresis SDS-PAGE}

The characterization of the protein fractions, from the original washing waters, concentrate and permeate from UF was carried out by electrophoresis with polyacrylamide gel in the presence of sodium dodecyl sulfate (SDS-PAGE), using Sigma brand products.

Running gel was made by mixing $1.38 \mathrm{~mL}$ of deionized water, $1.9 \mathrm{~mL}$ of $2.0 \mathrm{M}$ tris-HCL solution, $\mathrm{pH} 8.9,4 \mathrm{~mL}$ of acrylamide/bis solution (30\%/1.866\%) and $100 \mu \mathrm{L}$ of $10 \%$ sodium dodecyl sulfate (SDS) solution. Polymerization was carried out by adding $100 \mu \mathrm{L}$ of $10 \%$ ammonium persulfate and $8 \mu \mathrm{L}$ of tetramethyl-ethylenediamine (TEMED).

The stacking gel consisted of $1.19 \mathrm{~mL}$ of deionized water, $405 \mu \mathrm{L}$ of tris-HCL $2 \mathrm{M}$ solution $\mathrm{pH} 6.8,335 \mu \mathrm{L}$ of acrylamide/ bis $(30 \% / 1.866 \%)$ and $20 \mu \mathrm{L}$ of $10 \%$ SDS. Polymerization was carried out with $20 \mu \mathrm{L}$ of $10 \%$ ammonium persulfate and $4 \mu \mathrm{L}$ of TEMED.

The 10-fold concentrated running buffer solution consisted of $30.2 \mathrm{~g}$ of tris base, $188 \mathrm{~g}$ of glycine and $10 \mathrm{~g}$ of SDS in $1000 \mathrm{~mL}$ of

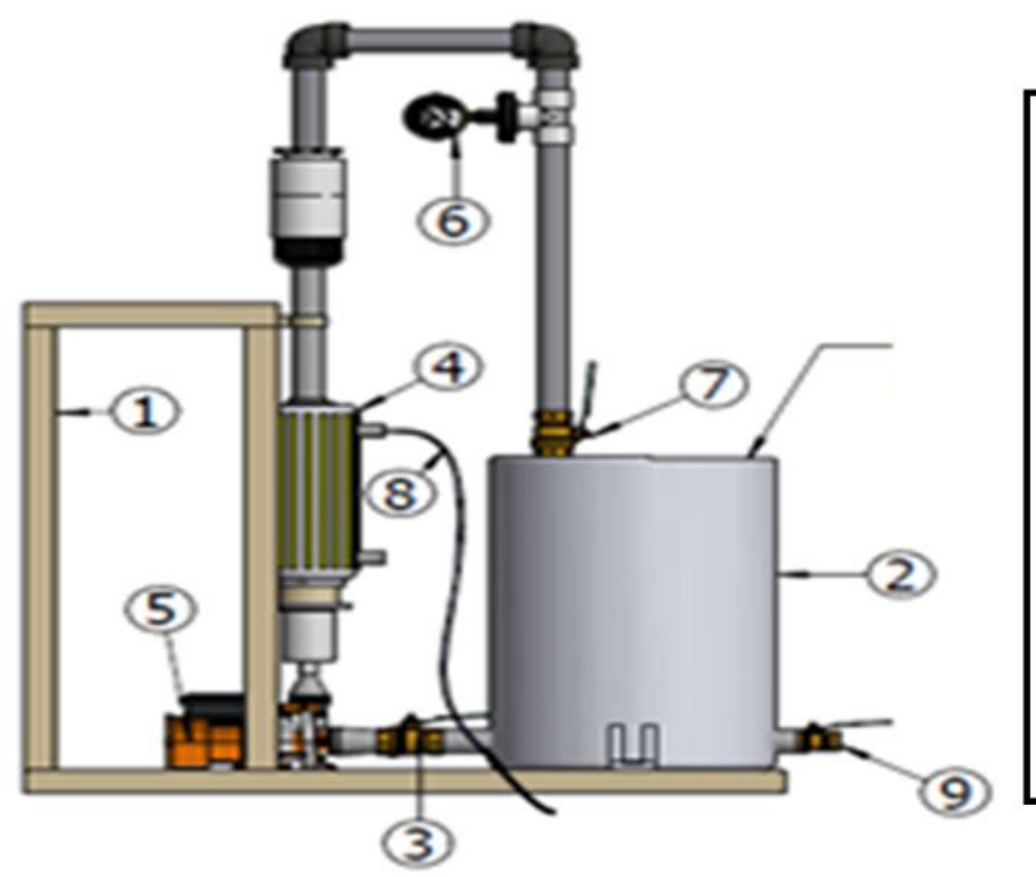

1 - Support

2 - Feed tank (25 L)

3 - Flow control valve

4 - Membrane

5 - Feed pump

6 - Manometer

7 - Flow control valve

8 - Permeate

9 - Concentrate

Figure 1. Pilot ultrafiltration system. 
distilled water. The sample buffer solution consisted of $10 \mathrm{~mL}$ of $10 \%$ sodium lauryl sulfate, $4 \mathrm{~mL}$ of $0.5 \mathrm{M}$ EDTA, $5 \mathrm{~mL}$ of $0.617 \mathrm{M}$ tris-phosphate ( $\mathrm{pH} 6.8$ ), $3 \mathrm{~mL}$ of mercaptoethanol, $10 \mathrm{~mL}$ of glycerol, $18 \mathrm{~mL}$ of deionized water and $5 \mathrm{mg}$ of bromophenol blue.

For the electrophoresis, $10 \mu \mathrm{L}$ of the samples (original water and permeate in pure form and concentrate diluted 1:10 in deionized water) were added with $10 \mu \mathrm{L}$ of sample buffer in $0.5 \mathrm{~mL}$ microtubes, boiled at $95^{\circ} \mathrm{C}$ during $10 \mathrm{~min}$ for denaturation of proteins and applied to the gel $(20 \mu \mathrm{L})$. A vertical electrophoresis tank was used, connected to the power source programmed at $250 \mathrm{~mA}$ with a voltage of $180 \mathrm{~V}$ for $2 \mathrm{~h}$. The protein bands were visualized from the gel stained with PAGE BLUE dye (Sigma-Aldrich, St. Louis, MO). After washing the gel in deionized water, protein fractions were identified using an 11-245 kDa molecular weight marker (Sigma-Aldrich, St. Louis, MO).

\subsection{Amino acids profile and protein content determination in the concentrate}

The concentrate was dehydrated in a spray dryer MSD 1.0 (Labmaq do Brasil, Ribeirão Preto, SP) at $120{ }^{\circ} \mathrm{C}$, with a feed rate of $0.81 \mathrm{~L} / \mathrm{h}$ and compressed airflow of $30 \mathrm{~L} / \mathrm{min}$.

The amino acids were extracted in $\mathrm{HCl} 6 \mathrm{~N}$ and phenol, neutralized and derivatized in a pre-column system with phenylisothiocyanate. Quantification was performed by high-performance liquid chromatography in reverse phase, with detection at $254 \mathrm{~nm}$, using alpha-aminobutyric acid as an internal standard. Tryptophan was extracted by enzymatic hydrolysis, detected in a spectrophotometer at $590 \mathrm{~nm}$ and quantified by an external standard. The percentage of proteins was determined by the micro Kjeldhal method ( $\mathrm{x}$ 6.25) (Horwitz \& Latimer, 2006).

\subsection{Carotenoid content in the concentrate}

The dehydrated concentrate was vortexed with dimethyl sulfoxide after sonication for 15 minutes at $40^{\circ} \mathrm{C}$. The extraction was carried out repeatedly with acetone. Phase separation was obtained with diethyl ether and distilled water, and the hyper phase was dried with nitrogen. The absorbance of the extract resuspended in ethanol was read at $475 \mathrm{~nm}$ and the concentration of total carotenoids was calculated with Equation 2, using 2500 as the coefficient extinction.

$C C(\mathrm{mg} /$ sampleweight $)=\frac{(A \times 2 \times 1000)}{2500 \times 100}$ where CC: carotenoid concentration; A: absorbance.

\subsection{Statistical analysis}

The results were subjected to analysis of variance and the means were compared using the Tukey test, using the statistical package SAS (Statistical Analysis System, version 9.3), with a significance level of $5 \%$.

\section{Results and discussion}

The comparison between TS, protein content and COD levels of the original waters and the permeate (Table 1) showed a significant reduction after UF with a $30 \mathrm{kDa}$ membrane, especially COD (99\%, $\mathrm{p}<0.05)$, indicating the efficiency of the process in removing the organic load from the water generated during the fabrication of surimi.

Resolution CONAMA 430/2011, which regulates national standards for the discharge of effluents into water masses, does not establish limits for COD. However, some state environmental laws in Brazil establish maximum limits for this parameter, such as the Joint Normative COPAM 01/2008, which establishes a limit of up to $180 \mathrm{mg} / \mathrm{L}$ for COD for the discard of effluents on environment (Minas Gerais, 2008). Resolution COMDEMA $34 / 2012$ establishes a maximum of $100 \mathrm{mg} / \mathrm{L}$ COD for the direct discharge of effluents from treatment systems from any polluting source (Manaus, 2012). As federal law does not have a ceiling value to be met for COD, states have autonomy to adopt standards that are more suited to their environmental and economic context, establishing their own limits according to the industrial or enterprise typology.

Thus, the COD values found in this study $(142.72 \mathrm{mg} / \mathrm{L})$ are within the limit established by COPAM 01/2008 and above that established by COMDEMA 34/2012. According to Wiesner et al. (1994), for waters with low COD concentrations, UF treatment may be sufficient to give this effluent a high quality.

Afonso \& Bórquez (2002) state that membrane filtration techniques are able to reduce the polluting load of the water, resulting in a good quality permeate which can be reused in the industry, in addition to being cheaper than thermal treatments. Lin et al. (1995) also refer to a treatment with a UF membrane of $30 \mathrm{kDa}$ for the filtration of surimi washing water, noting that the process made it possible to reuse the water for cleaning or supplying toilets, among others.

Table 1. Analyses of surimi washing water (original) and permeate obtained after ultrafiltration (means \pm standard deviations).

\begin{tabular}{|c|c|c|c|c|c|}
\hline Parameter & Original & $\mathrm{CV}(\%)$ & Permeate & CV (\%) & Reduction (\%) \\
\hline Total solids (mg/L) & $7.9 \pm 0.96^{\mathrm{a}}$ & 12.1 & $2.9 \pm 0.51^{\mathrm{b}}$ & 17.3 & 63 \\
\hline Fixed solids $(\mathrm{mg} / \mathrm{L})$ & $1.1 \pm 0.15$ & 13.9 & $0.9 \pm 0.16$ & 16.6 & 14 \\
\hline $\mathrm{COD}(\mathrm{mg} / \mathrm{L})^{1}$ & $142.7 \pm 32.52^{\mathrm{a}}$ & 22.8 & $1.8 \pm 0.07^{\mathrm{b}}$ & 0.96 & 99 \\
\hline Lipids (mg/L) & $0.7 \pm 0.15$ & 20.6 & $0.1 \pm 0.04$ & 32.1 & 84 \\
\hline Proteins $(\mu \mathrm{g} / 10 \mu \mathrm{L})$ & $19.2 \pm 0.92^{\mathrm{a}}$ & 4.80 & $1.3 \pm 0.41^{\mathrm{b}}$ & 30.9 & 93 \\
\hline $\mathrm{pH}$ & $6.5 \pm 0.01$ & 0.15 & $6.3 \pm 0.25$ & 3.97 & - \\
\hline
\end{tabular}

${ }^{1}$ COD: Chemical Oxygen Demand. Means followed by different letters in the row differed by Tukey's test $(\mathrm{p}<0.05)$. CV: coefficient of variation. 
According to Oenning \& Pawlowsky (2007) the maximum COD requirement that allows the reuse of treated water from effluents in cooling and sanitary towers is $75 \mathrm{mg} / \mathrm{L}$ and $25 \mathrm{mg} / \mathrm{L}$ for washing floors and irrigating industrial green areas. Taking these studies as a base, the permeate resulting from the UF of the surimi washing waters $(1.8 \mathrm{mg} / \mathrm{L} \mathrm{COD})$ could be reused in the industrial installation itself, representing a water saving.

There were no changes in FS, OG, and $\mathrm{pH}$ values after application of UF. However, the values found for OG and $\mathrm{pH}$ were already within the discharge standards required by legislation (Resolution CONAMA No. 430/2011), which are, respectively, up to $50 \mathrm{mg} / \mathrm{L}$ and between 5 and 9 (Brasil, 2011).

The concentrate resulting from the UF of the surimi washing waters showed $14.87 \mathrm{mg} / \mathrm{L}$ of TS, $1.26 \mathrm{mg} / \mathrm{L}$ of FS, $0.87 \mathrm{mg} / \mathrm{L}$ of lipids, $5.98 \mathrm{of} \mathrm{pH}$ and $37.66 \mu \mathrm{g} / 10 \mu \mathrm{L}$ of protein, which represented a recovery of $93.12 \%$ of the total proteins. Different contents of solids and proteins can be recovered by membrane filtration, depending on factors such as the species of fish used in the processing, membrane cutoff $(\mathrm{kDa})$, membrane material and number of washes performed in the elaboration of surimi.

DeWitt \& Morrissey (2002), for example, using a membrane similar to that of the present study, found $24.38 \mathrm{mg} / \mathrm{mL}$ of TS, $3.74 \mathrm{mg} / \mathrm{mL}$ of FS and $19.69 \mathrm{mg} / \mathrm{mL}$ of proteins in the concentrate. According to the authors, more solids/proteins passed into the permeate when a $50 \mathrm{kDa}$ membrane was used for filtration. Stine et al. (2012), recovered $80 \%$ of the protein contained in the surimi washing waters using a UF membrane with a cutoff point of $50 \mathrm{kDa}$ and Yeong et al. (2002) recovered $95.1 \%$ of protein in the waters obtained in the first wash using a nanofiltration system with $500 \mathrm{Da}$ polyamide membrane.

\subsection{Electrophoresis SDS-PAGE}

The washing and draining operations used in the preparation of surimi are designed to eliminate sarcoplasmic proteins and retain myofibrillar proteins. Despite the large amount of sarcoplasmic proteins shown by the bands in the range from 39 to $41 \mathrm{kDa}$ in the original water (Figure 2, column 2), the washing operations performed in the elaboration of surimi also caused the passage of part of the myofibrillar proteins, which have bands close to $200 \mathrm{kDa}$ (myosin heavy chains), $70 \mathrm{kDa}$ (light meromyosin), between 20 and $25 \mathrm{kDa}$ (myosin light chains) and between 43 and $45 \mathrm{kDa}$ (actin) (Lin \& Park, 1996; Zhou et al., 2016).

The loss of myofibrillar proteins in the surimi washing waters can be associated with extensive washing and the mechanical force performed during the removal of water (Lin et al., 1995). According to Lin \& Park (1996), the elimination of myofibrillar proteins occurs after the second wash, increasing as the number of washing cycles increases. The lower PM bands in the original waters refer to low molecular weight peptides and amino acids (Ding et al., 2017; Zhou et al., 2016), formed due to the partial degradation of proteins in the production process.

The electrophoretic profile of the concentrate (column 4) showed that UF was able to retain most of the proteins, peptides and amino acids present in the surimi washing waters, reinforcing

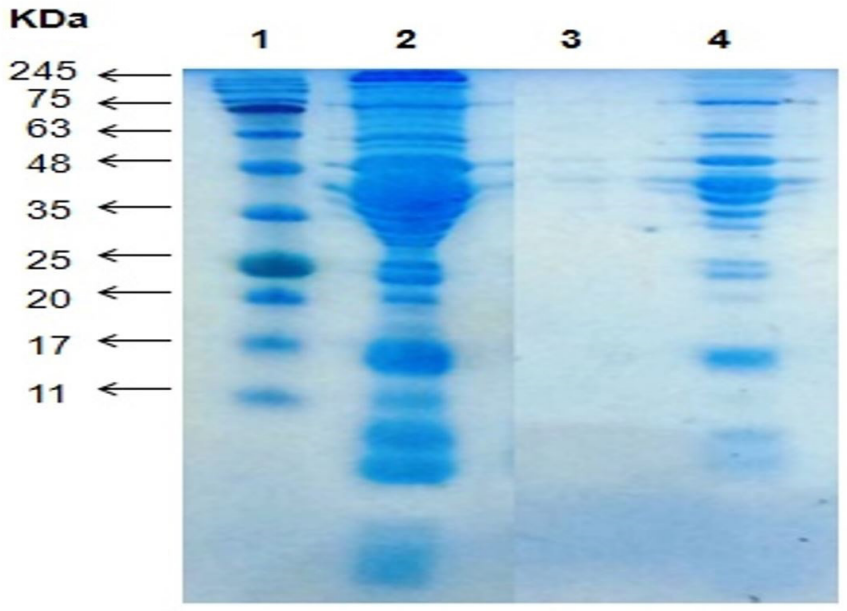

Figure 2. SDS - PAGE of surimi washing water. (1) molecular weight $(\mathrm{kDa}) ;(2)$ original water; (3) permeate; (4) concentrate.

the potential of the technique for the recovery of substances of interest in the food industry.

\subsection{Amino acids, proteins and carotenoids in the concentrate}

The resulting UF concentrate contained $66.49 \%$ amino acids, including all essentials for humans, with leucine, lysine, valine and phenylalanine having the highest concentrations, higher than the concentrations present in soy (Table 2) (Wibowo et al., 2007).

The chemical composition of the protein concentrate obtained in this study favors its use as an ingredient for the preparation and enrichment of food products, as it happens with the mechanically separated meat (MSM) obtained from residues from the industrialization of fish. In comparison with the tilapia (Oreochromis niloticus) MSM produced by Fogaça et al. (2015), the protein concentrate obtained in this study showed higher concentrations of essential amino acids (Table 2).

In addition, the physical form of the product developed in this study represents an additional advantage for its use as an ingredient, since, in powder form, its incorporation into the preparations is facilitated. Oliveira et al. (2019) added dehydrated protein recovered from the surimi washing waters by UF in fishburgers made with surimi and realized that the use of this protein as an ingredient can improve the sensory and nutritional aspects of the final product.

Amino acids included as ingredients to a food item can sensorially influence the final products, since they play an important role in the aroma, color and flavor of food (Food Ingredients Brasil, 2014). For example, threonine, glycine, serine, proline, lysine and alanine influence the intensity of the sweet taste, while phenylalanine, tyrosine, leucine, valine and isoleucine are responsible for the bitter taste, often rejected by consumers (Egerton et al., 2018; Food Ingredients Brasil, 2014). Aspartic acid and glutamic acid are associated with umami flavor, characteristic of foods such as nuts, mushrooms, fish, crustaceans, meat, cabbage, spinach, ripe tomatoes, green tea, cheese and soy sauce (Food Ingredients Brasil, 2014; Shen et al., 2012). Therefore, the amount of protein concentrate that can be used in 
Table 2. Amino acid composition, protein and carotenoid concentrations in the dehydrated concentrate resulting from the UF of the surimi washing waters $(\mathrm{g} / 100 \mathrm{~g})$. Literature values added for comparison.

\begin{tabular}{|c|c|c|c|c|}
\hline Amino acids & $\begin{array}{l}\text { Dehydrated } \\
\text { concentrate }\end{array}$ & $\mathrm{CMS}^{1}$ & Soy $^{2}$ & $\mathrm{FAO} / \mathrm{WHO}^{3}$ \\
\hline Phenylalanine & 3.68 & 0.74 & 3.1 & 0.025 \\
\hline Isoleucine & 3.35 & 0.37 & 2.9 & 0.020 \\
\hline Lysine & 6.49 & 1.86 & 3.7 & 0.030 \\
\hline Leucine & 5.47 & 1.00 & 4.5 & 0.039 \\
\hline Methionine & 1.59 & 0.27 & 0.8 & 0.010 \\
\hline Histidine & 2.42 & 0.38 & 1.2 & 0.015 \\
\hline Threonine & 3.03 & 0.78 & 1.8 & 0.015 \\
\hline Tryptophan & 0.50 & 0.77 & - & 0.004 \\
\hline Valine & 3.59 & 0.77 & 3.4 & 0.026 \\
\hline Proline & 2.28 & 0.83 & - & - \\
\hline Tyrosine & 1.84 & 0.56 & - & - \\
\hline Alanine & 4.38 & 1.08 & - & - \\
\hline Taurine & 0.26 & - & - & - \\
\hline Cystine & 0.72 & - & - & - \\
\hline Glutamic acid & 7.83 & 2.56 & - & - \\
\hline Aspartic acid & 8.85 & 1.71 & - & - \\
\hline Glycine & 4.24 & 1.13 & - & - \\
\hline Serine & 2.65 & 0.72 & - & - \\
\hline Arginine & 3.37 & 1.29 & - & - \\
\hline Crude protein (\%) & 67.35 & & & \\
\hline $\begin{array}{l}\text { Total carotenoids } \\
(\mathrm{mg} / 100 \mathrm{~g})\end{array}$ & 0.67 & & & \\
\hline
\end{tabular}

${ }^{1}$ CMS: mechanically separated meat. Fogaça et al. (2015); ${ }^{2}$ Wibowo et al. (2007); ${ }^{3}$ Daily requirements for essential amino acids in adults (World Health Organization, 2007).

a food formulation should be determined in order to maximize or minimize certain flavors.

In addition, if the intended use for a product containing the protein concentrate is in the baked form, the presence of glycine and lysine may favor the appearance of a golden aspect, since these amino acids have high reactivity in the Maillard reaction, (Food Ingredients Brasil, 2014; Francisquini et al., 2017).

More than the application as an ingredient, the dehydrated concentrate can also find use as a nutritional supplement, following the increasingly popular trend, especially among athletes, the elderly and people who use restrictive diets. Milk and soy are the main sources of protein used in nutritional supplements, with whey protein being the most widely used (Galaz, 2019). For comparison, in $40 \mathrm{~g}$ of a protein supplement based on whey proteins, there are on average $25 \mathrm{~g}$ of protein, $1.358 \mathrm{mg}$ of valine, $1.460 \mathrm{mg}$ of isoleucine and $2.508 \mathrm{mg}$ of leucine, that are concentrations lower than those present in $40 \mathrm{~g}$ of the dehydrate concentrate obtained in the present study (1436.00 mg of valine, $1340.00 \mathrm{mg}$ of isoleucine and $2188.00 \mathrm{mg}$ of leucine). These branched chain amino acids (BCAA) are essential and highly looked after by people who want to develop muscle (Shimomura et al., 2004).
According to World Health Organization (2007), the daily leucine recommendation is $39 \mathrm{mg} / \mathrm{kg}$. Considering that a $70 \mathrm{~kg}$ adult needs $2730.00 \mathrm{mg} / \mathrm{kg}$ per day of leucine, to reach the recommended amount of this amino acid, $50 \mathrm{~g}$ of UF concentrate from surimi washing waters would be sufficient. The same reasoning applies to all other BCAAs, and to achieve the daily recommendations for valine and isoleucine, $51 \mathrm{~g}$ and $41 \mathrm{~g}$ of UF concentrate would be sufficient. The consumption of BCAA amino acids provides an increase in the synthesis of muscle proteins and reduction of their degradation, shortening the recovery time after exercise, increased muscle endurance, decreased muscle fatigue, energy generation during exercise and preservation of muscle glycogen (Shimomura et al., 2004). Thus, the product obtained in this experiment could be used as a nutritional supplement for human consumption, according to these objectives.

The concentrate obtained by Stine et al. (2012) after filtering the surimi washing water at $80 \mathrm{kDa}$, presented histidine $(2.9 \%)$, glycine (4.45\%) and threonine (4.5\%), similarly to the amino acids found in surimi, suggesting its application in fish-based products.

In addition to the amino acids, the concentrate resulting from the UF of the surimi washing waters contained $0.67 \mathrm{mg} / 100 \mathrm{~g}$ of carotenoids. This fact may be associated with the formation of a complex between carotenoids and proteins, called carotene-protein. Carotene-protein is normally used as a food supplement in fish feed that, like other animals, does not synthesize carotenoids. These substances reach animal organisms through food and some of them can be converted into other carotenoids via oxidation or reduction and into vitamin A (Chakrabarti, 2002; Czeczuga et al., 2013).

The present study demonstrated that the proteins eliminated in the surimi washing waters have high nutritional value and their waste is inopportune, in view of the food growing needs of the population. The treatment proposed in this study proved to be suitable not only for the concentration of these substances, but also to enable the reuse of wastewater. With these results, we hope to provide subsidies for the fish processing industry to invest in the efficient use of water and, still, obtain additional profits with the production of a nutritional supplement.

\section{Conclusion}

The application of UF reduced the organic matter in the surimi washing waters and allowed the obtaining of a protein concentrate containing essential amino acids and carotenoids, which can be used by the food industry.

\section{Acknowledgements}

CAPES and Fapesp Project number 2015/25853-1 for the scholarship.

\section{References}

Afonso, M. D., \& Bórquez, R. (2002). Review of the treatments of seafood processing wastewaters and recovery of proteins therein by membrane separation processes: prospects of the ultrafiltration of wastewaters from the fish meal industry. Desalination, 142(1), 29-45. http://dx.doi.org/10.1016/S0011-9164(01)00423-4. 
American Public Health Association - APHA, American Water Works Association - AWWA, Water Environment Federation - WPCF. (2005). Standard methods for the examination of water and wastewater (20th ed.). Washington: APHA.

Brasil, Conselho Nacional do Meio Ambiente - CONAMA. (2011, May 16). Dispõe sobre as condições e padrões de lançamento de efluentes, complementa e altera a Resolução nº 357, de 17 de março de 2005, do Conselho Nacional do Meio Ambiente - CONAMA (Resolução no 430, de 13 de maio de 2011). Diário Oficial da República Federativa do Brasil. Retrieved from http://www.mma.gov.br/port/ conama/legiabre.cfm? codlegi $=646$

Chakrabarti, R. (2002). Carotenoprotein from tropical brown shrimp shell waste by enzymatic process. Food Biotechnology, 16(1), 81-90. http://dx.doi.org/10.1081/FBT-120004202.

Czeczuga, B., Semeniuk, J., Czeczuga-Semeniuk, E., Semeniuk, A., \& Klyszejko, B. (2013). Amount and qualities of carotenoids in fillets of fish species fed natural feed in some fisheries of West African Coast. African Journal of Biotechnology, 12(12), 1443-1448.

DeWitt, C. A. M., \& Morrissey, M. T. (2002). Pilot plant recovery of catheptic proteases from surimi wash water. Bioresource Technology, 82(3), 295-301. http://dx.doi.org/10.1016/S0960-8524(01)00178-X. PMid:11991080.

Ding, H. C., Li, D. F., Wei, X. Y., Huang, Y. W., Cui, S., Xie, H. J., \& Zhou, T. (2017). Protein-peptide nutritional material prepared from surimi wash -water using immobilized chymotrypsin-trypsin. Journal of the Science of Food and Agriculture, 97(6), 1746-1752. http://dx.doi. org/10.1002/jsfa.7969. PMid:27465270.

Egerton, S., Culloty, S., Whooley, J., Stanton, C., \& Ross, R. P. (2018). Characterization of protein hydrolysates from blue whiting (Micromesistius poutassou) and their application in beverage fortification. Food Chemistry, 245, 698-706. http://dx.doi.org/10.1016/j. foodchem.2017.10.107. PMid:29287428.

Fogaça, F. H. S., Otani, F. S., Portella, C. G., Santos-Filho, L. G. A., \& Sant'Ana, L. S. (2015). Caracterização de surimi obtido a partir da carne mecanicamente separada de tilapia do Nilo e elaboração de fishburger. Semina: Ciências Agrárias, 36(2), 765-776. http:// dx.doi.org/10.5433/1679-0359.2015v36n2p765.

Food and Agriculture Organization - FAO. (2016). The state of world fisheries and aquaculture 2016: part one: world review. Rome: FAO. Retrieved from http://www.fao.org/3/a-i5555e.pdf

Food and Agriculture Organization - FAO. (2018). The state of world fisheries and aquaculture 2018: meeting the sustainable development goals. Rome: FAO. Retrieved from http://www.fao.org/3/i9540en/ I9540EN.pdf

Food Ingredients Brasil - FIB. (2014). Os aminoácidos e o sabor. Food Ingredients Brasil, 16(31), 70-76.

Francisquini, J. A., Martins, E., Silva, P. H. F., Schuck, P., Perrone, I. T., \& Carvalho, A. F. (2017). Reação De Maillard: uma revisão. Revista do Instituto de Latícinios Cândido Tostes, 72(1), 48-57. http://dx.doi. org/10.14295/2238-6416.v72i1.541.

Galaz, G. A. (2019). An overview on the history of sports nutrition beverages. In D. Bagchi, S. Nair \& C. K. Sen (Eds.), Nutrition and enhanced sports performance (pp. 231-237). Cambridge: Academic Press. http://dx.doi.org/10.1016/B978-0-12-813922-6.00019-9.

Galvão, G. C. D. S., Lourenço, L. D. F. H., Ribeiro, S. D. C. A., Ribeiro, C. D. F. A., Park, K. J., \& Araujo, E. A. F. (2012). Microbiological and physicochemical characterization of surimi obtained from waste of piramutaba fillet. Food Science and Technology, 32(2), 302-307. http://dx.doi.org/10.1590/S0101-20612012005000058.
Horwitz, W., \& Latimer, G. H. Jr. (Eds.). (2006). Official methods of analysis of AOAC International (18th ed.). Gaithersburg: AOAC International.

Huang, L., \& Morrissey, M. T. (1998). Fouling of membranes during microfltration of surimi wash water: roles of pore blocking and surface cake formation. Journal of Membrane Science, 144(1-2), 113-123. http://dx.doi.org/10.1016/S0376-7388(98)00038-6.

Huang, L., Chen, Y., \& Morrissey, M. T. (1997). Coagulation of fish proteins from frozen fish mince wash water by ohmic heating. Journal of Food Process Engineering, 20(4), 285-300. http://dx.doi. org/10.1111/j.1745-4530.1997.tb00423.x.

Lee, C. M. (1984). Surimi process technology. Food Technology, 38(11), 69-80.

Lin, T. M., \& Park, J. W. (1996). Effective washing conditions reduce water usage for surimi processing. Journal of Aquatic Food Product Technology, 6(2), 65-79. http://dx.doi.org/10.1300/J030v06n02_06.

Lin, T. M., Park, J. W., \& Morrissey, M. T. (1995). Recovered protein and reconditioned water from surimi processing waste. Journal of Food Science, 60(1), 4-9. http://dx.doi.org/10.1111/j.1365-2621.1995. tb05594.x.

Liu, S. X. (2007). Food and agricultural utilization and treatment (1st ed.). Ames: Blackwell.

Manaus, Conselho Municipal de Desenvolvimento e Meio Ambiente COMDEMA. (2012). Estabelece normas e padrões para qualidade das águas, condições para lançamento de efluentes e dá outras providências (Resolução $\mathrm{n}^{\circ}$ 34, de 27 de julho de 2012). Diário Oficial do Município de Manaus.

Minas Gerais, Conselho Estadual de Política Ambiental - COPAM, Conselho Estadual de Recursos Hídricos do Estado de Minas Gerais - CERH. (2008, 13 May). Deliberação normativa conjunta $\mathrm{n}^{\circ} 01$, de 5 de maio de 2008. Jornal Minas Gerais. Retrieved from http://www2.mma.gov.br/port/conama/processos/EFABF603/ DeliberaNormativaConjuntaCOPAM-CERHno01-2008.pdf

Oenning, A. Jr., \& Pawlowsky, U. (2007). Avaliação de tecnologias avançadas para o reúso de água em indústria metal-mecânica. Engenharia Sanitaria e Ambiental, 12(3), 305-316. http://dx.doi. org/10.1590/S1413-41522007000300010.

Oliveira, D. L., Grassi, T. L. M., Bassani, J. S., Diniz, J. C. P., Paiva, N. M., \& Ponsano, E. H. G. (2019). Enrichment of fishburgers with proteins from surimi washing water. Food Science and Technology. In press. http://dx.doi.org/10.1590/fst.21319.

Oliveira, D. L., Grassi, T. L. M., Santo, E. F. E., Cavazzana, J. F., Marcos, M. T. S., \& Ponsano, E. H. G. (2017). Washings and cryoprotectants for the production of Tilapia Surimi. Food Science and Technology, 37(3), 432-436. http://dx.doi.org/10.1590/1678-457x.18716.

Park, J. W., \& Morrissey, M. T. (2000). Manufacturing of surimi from light muscle fish. In J. W. Park (Ed.), Surimi and surimi seafood (pp. 23-58). New York: Marcel Dekker.

Shen, Q., Guo, R., Dai, Z., \& Zhang, Y. (2012). Investigation of enzymatic hydrolysis conditions on the properties of protein hydrolysate from fish muscle (Collichthys niveatus) and evaluation of its functional properties. Journal of Agricultural and Food Chemistry, 60(20), 5192-5198. http://dx.doi.org/10.1021/jf205258f. PMid:22530872.

Shimomura, Y., Murakami, T., Nakai, N., Nagasaki, M., \& Harris, R. A. (2004). Exercise promotes BCAA catabolism: effects of BCAA supplementation on skeletal muscle during exercise. The Journal of Nutrition, 134(6, Suppl.), 1583S-1587S. http://dx.doi.org/10.1093/ jn/134.6.1583S. PMid:15173434. 
Stine, J. J., Pedersen, L., Smiley, S., \& Bechtel, P. J. (2012). Recovery and utilization of protein derived from surimi wash-water. Journal of Food Quality,35(1), 43-50.http://dx.doi.org/10.1111/j.1745-4557.2011.00424.x.

Suzuki, T. (1987). Tecnología de las proteinas de pescado y krill. Zaragoza: Acribia.

Wibowo, S. V., Savant, V., Cherian, G., Savage, T. F., Velazquez, G., \& Torres, J. A. (2007). A feeding study to assess nutritional quality and safety of surimiwashwater proteins recovered by a chitosan-alginate complex. Journal of Food Science, 2(3), 179-184. http://dx.doi.org/10.1111/j.1750-3841.2007.00291.x. PMid:17995811.

Wiesner, M. R., Hackney, J., Sethi, S., Jacangelo, J. G., \& Laîé, J.-M. (1994). Cost estimates for membrane filtration and conventional treatment. Journal - American Water Works Association, 85(12), 3341. http://dx.doi.org/10.1002/j.1551-8833.1994.tb06284.x.
World Health Organization - WHO. (2007). Protein and aminoacid requirements in human nutrition: report of a joint WHO/FAO/ UNU expert consultation (Technical Report Series, No. 935). Geneva: WHO.

Yeong, W. T., Mohammad, A. W., Anuar, N., \& Rahman, R. A. (2002). Potential use of nanofiltration membrane in treatment of wastewater from fish and surimi industries. Songklanakarin Journal of Science and Technology, 24(Suppl.), 977-987.

Zhou, Q. W., Ding, H. C., Li, D. F., Zhang, Y. P., Dai, Z. Y., \& Zhou, T. (2016). Antioxidant activity of enzymatic hydrolysate derived from hairtail surimi wash water using an immobilized chymotrypsintrypsin column reactor. Journal of Food Biochemistry, 40(1), 39-46. http://dx.doi.org/10.1111/jfbc.12185. 